\title{
OPEN An under-ice bloom of mixotrophic haptophytes in low nutrient and freshwater-influenced Arctic waters
}

\begin{abstract}
Dorte H. Søgaard ${ }^{1,2 \bowtie}$, Brian K. Sorrell ${ }^{2}$, Mikael K. Sejr ${ }^{2,3}$, Per Andersen ${ }^{3}$, Søren Rysgaard ${ }^{1,2,4}$, Per Juel Hansen ${ }^{5}$, Annaliina Skyttä6, Signe Lemcke² \& Lars Chresten Lund-Hansen ${ }^{2}$

The pelagic spring bloom is essential for Arctic marine food webs, and a crucial driver of carbon transport to the ocean depths. A critical challenge is understanding its timing and magnitude, to predict its changes in coming decades. Spring bloom onset is typically light-limited, beginning when irradiance increases or during ice breakup. Here we report an acute 9 -day under-ice algal bloom in nutrient-poor, freshwater-influenced water under 1-m thick sea ice. It was dominated by mixotrophic brackish water haptophytes (Chrysochromulinal Prymnesium) that produced $5.7 \mathrm{~g} \mathrm{C} \mathrm{m}^{-2}$ new production. This estimate represents about half the annual pelagic production, occurring below sea ice with a large contribution from the mixotrophic algae bloom. The freshwater-influenced, nutrientdilute and low light environment combined with mixotrophic community dominance implies that phagotrophy played a critical role in the under-ice bloom. We argue that such blooms dominated by potentially toxic mixotrophic algae might become more common and widespread in the future Arctic Ocean.
\end{abstract}

Satellite-based remote sensing data suggest that annual pelagic net primary production in shelf areas of the Arctic Ocean has increased by $20 \%$ from 1998 to 2009 , mainly due to the longer seasonal duration of the ice-free period, and thus a longer pelagic growth season ${ }^{1}$. The contribution of phytoplankton productivity beneath ice-covered oceans to annual pelagic net primary production was until recently thought to be negligible, primarily because of the strong light attenuation by snow and sea ice ${ }^{2}$. However, this view has recently been challenged by observations of extensive diatom-dominated under-ice blooms beneath thick melting sea ice or under refrozen leads ${ }^{3-5}$. In these studies, diatom- and Phaeocystis-dominated under-ice blooms were triggered by increased under-ice irradiance due to melting sea ice, refrozen leads and/or melt pond formation (i.e. increased transmittance) and were fuelled by an excess of nutrients in the under-ice waters ${ }^{3-7}$. However, an improved understanding of the role, extent and frequency of these extensive under-ice blooms is needed to describe and model future changes in annual pelagic net primary productivity in the Arctic Ocean.

The Young Sound fjord in NE Greenland is covered by sea ice for most of the year $(8-10 \text { months })^{8}$ and has a pronounced summer stratification that impedes nutrient supply from deeper waters ${ }^{9,10}$. The combination of light limitation by sea ice and terrestrial run-off and low nutrient supply in Young Sound is responsible for its low annual pelagic net primary productivity $\left(10.3 \mathrm{~g} \mathrm{C} \mathrm{m}^{-2} \mathrm{year}^{-1}\right)^{8,11}$, which is low compared to the more productive Godthåbsfjord on the southwest coast of Greenland (between 84.6 and $139.1 \mathrm{~g} \mathrm{C} \mathrm{m}^{-2}$ year $^{-1}$ ) ${ }^{12}$. The future annual pelagic net primary production in Young Sound and across the Arctic Ocean is likely to increase overall as the ice-free season lengthens. Counteracting the effects of a longer pelagic growing season is, however, the recent increase in freshwater fluxes from Arctic glaciers and the general freshening of the Young Sound fjord, adjacent

\footnotetext{
${ }^{1}$ Greenland Climate Research Centre (C/O Greenland Institute of Natural Resources), Kivioq 2, Box 570, 3900 Nuuk, Greenland. '2Department of Biology, Arctic Research Centre, Aarhus University, Ole Worms Allé 1, Build. 1135, 8000 Aarhus C, Denmark. ${ }^{3}$ Department of Bioscience, Aarhus University, Vejlsøvej 25, 8000 Silkeborg, Denmark. ${ }^{4}$ Centre for Earth Observation Science, CHR Faculty of Environment Earth and Resources, University of Manitoba, Winnipeg, MB, Canada. ${ }^{5}$ Faculty of Science, Marine Biological Section, University of Copenhagen, Strandpromenaden 5, 3000 Helsingør, Denmark. ${ }^{6}$ Faculty of Biological and Environmental Sciences Research Infrastructure-Core Facilities, University of Helsinki, Fabianinkatu 33, P.O. Box 3, 00014 Helsinki, Finland. ${ }^{\boxplus}$ email: doso@natur.gl
} 
fjords ${ }^{13,14}$ and the Arctic Ocean ${ }^{15,16}$. This freshening may lead to an intensified stratification and therefore a weakened vertical supply of nutrients ${ }^{9,17}$.

In this study, we demonstrate for the first time an under-ice bloom driven by mixotrophic brackish-water haptophytes beneath $1-\mathrm{m}$ thick sea ice in a nutritionally dilute environment. These haptophyte genera (Prymnesium and Chrysochromulina) can be highly toxic to fish and cause severe damage to the aquaculture industry, e.g. in Norway ${ }^{18,19}$. Harmful blooms of Chrysochromulina spp. have been observed in the Skagerrak/Kattegat ${ }^{18-20}$, the Baltic Sea ${ }^{21}$, and in Resolute Bay, Canada ${ }^{22}$, but this is, to our knowledge, the first observation of a high Arctic under-ice bloom driven by mixotrophic haptophytes.

Species of Prymnesium and Chrysochromulina are mixotrophs, combining photosynthesis and prey uptake. This provides them with a competitive advantage in light- and nutrient-limited environments ${ }^{23-28}$. Predation/ grazing provides mixotrophic Chrysochromulina species with organic carbon as an energy source as well as additional nitrogen, allowing them to grow when light is limiting photosynthesis or dissolved inorganic nutrients in the sea ice and seawater are low ${ }^{25-28}$. The concentration of haptophytes in the present bloom $\left(\sim 20 \times 10^{5} \mathrm{cells}^{-1}\right)$ was similar to those cell concentrations found during the peak of harmful Chrysochromulina blooms in the Skagerrak in southern Norway ${ }^{18,19}$. The indication of a mixotrophic-based bloom suggests that mixotrophic algae may play an important role in driving the Arctic spring bloom and thus the ecosystem and carbon dynamics in this area. Some haptophytes tend to be more abundant in less saline waters, as exemplified by records of Chrysochromulina spp. in the low saline (salinity 5-6) Baltic Sea and in the Kattegat (salinity 15-25) ${ }^{19-21}$. This further implies that mixotrophic-driven harmful algae blooms might become more common and widespread in a more freshwater-influenced future Arctic Ocean.

\section{Results and discussion}

Sea ice and water column properties. In this study, we document that a mixotrophic-driven under-ice bloom can be an important seasonal feature of Arctic fords. An improved insight into the extent and frequency of these extensive blooms driven by potentially mixotrophic haptophyte species underneath thick sea ice is fundamental for understanding and modelling future changes in Arctic Ocean pelagic net primary productivity. If blooms of potentially toxic algae become more common in the Arctic, this might have a large ecological and socio-economic impact.

The bloom was initiated in nutrient-poor brackish water under 1-m thick sea ice covered with melt ponds in the Young Sound fjord in Northeast Greenland. Surface melt ponds started to form on the sea ice from snow meltwater on 11 June 2017 (Fig. 1). Consequently, this period was characterized by a continuous increase in maximum under-ice PAR from $4.0 \mu \mathrm{mol}$ photons $\mathrm{m}^{-2} \mathrm{~s}^{-1}$ before melt pond formation (8 June 2017; Fig. 1b,c), to a daily maximum of $127.3 \mu \mathrm{mol}$ photons $\mathrm{m}^{-2} \mathrm{~s}^{-1}$ on 23 June, and similar on 15 July at ice break-up (Fig. 1a).

The continuous increase in melt pond coverage (maximum of $\sim 40 \%$ ) and sea ice thaw (from 0.95 to $0.75 \mathrm{~m}$ thickness) resulted in a nearly full desalination of the sea ice towards 12 July and a concomitant decrease in under-ice salinity on 9 July (Fig. 1d,e). The sea ice cover broke up on 15 July after which the ice floes were transported out of the fjord by winds and the tide.

Spring bloom initiated by mixotrophic haptophytes. Prior to the complete brine drainage from melt ponds and ice melt towards 12 July, primary productivity and algal biomass in the sea ice were five to ten-fold

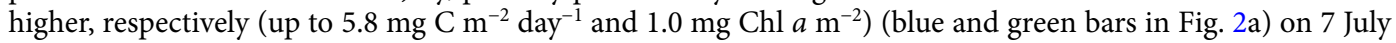
than after the drainage event on 15 July (sea ice algal productivity of $0.6 \mathrm{mg} \mathrm{C} \mathrm{m}^{-2}$ day $^{-1}$ and algal biomass of $0.2 \mathrm{mg} \mathrm{Chl} a \mathrm{~m}^{-2}$; blue and green bars in Fig. 2a). Furthermore, the total algal abundance in the sea ice on

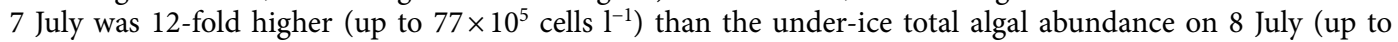
$6.2 \times 10^{5}$ cells $^{-1}$ ) (black line in Fig. 3). Based on bulk nutrient concentrations and bulk salinity in the sea ice, and the expected dilution line, we have calculated whether nutrients were depleted or whether production or net accumulation of nutrients had occurred at this site (Fig. 4). Sea ice nutrient-bulk salinity plots indicate accumulation of algal nutrients $\left(\mathrm{NO}_{\mathrm{x}}\right.$ and $\left.\mathrm{NH}_{4}{ }^{+}\right)$in the sea ice, which indicates that heterotrophic activity may have played an important role in nutrient re-cycling (Fig. 4). This is supported by the heavily undersaturated $\mathrm{O}_{2}$ concentrations in the sea ice (Fig. 2a, solid orange line). Together, these results suggest that the ice-associated heterotrophic productivity largely exceeded ice-associated primary productivity in this late season sea ice.

The complete drainage event towards 12 July marked the termination of the sea ice photosynthetic activity (sea ice algal biomass of $0.2 \mathrm{mg} \mathrm{Chl} a \mathrm{~m}^{-2}$; green bars in Fig. 2a). Therefore, the remaining sea ice algal community and algal nutrients present in the ice during melt likely sloughed from the sea ice to the under-ice seawater during the complete brine drainage towards 12 July. PAM fluorescence measurements verified that the drainage event ended the sea ice photosynthetic activity in the brine as demonstrated by a rapid decrease in maximum quantum yield $\left(F_{v} / F_{m}\right)$ of the sea ice from $0.21 \pm 0.07$ on 9 July to $0.11 \pm 0.04$ on 12 July (Table 1$)$.

These numbers are averages for the sectioned $(10 \mathrm{~cm})$ entire ice cores, and support the hypothesis that the complete brine drainage terminated the sea ice photosynthetic activity. Nevertheless, we observed a dramatic increase in under-ice water maximum quantum yield (Fv/Fm), biomass specific productivity and total algal abundance from $0.12 \pm 0.02,5.80 \mathrm{mg} \mathrm{C} \mathrm{mg} \mathrm{Chl} a^{-1}$ day $^{-1}$ and $6.2 \times 10^{5}$ cells $^{-1}$ on 9 July to a maximum of $0.35 \pm 0.10$,

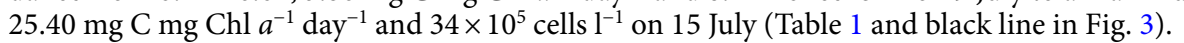

It could be argued that the bloom was simply related to advection of algae from open waters outside the fjord to the site below the ice, but this is contradicted by the simultaneous decrease in salinity (Fig. 1e). Under-ice salinities decreased due to rapid ice melt and freshwater drainage from melt ponds, and this signal would have been strongly dampened with any inflow of higher saline water. Furthermore, under-ice surface $(1 \mathrm{~m})$ water temperatures decreased from $0.3^{\circ} \mathrm{C}$ on 9 July to $0.07^{\circ} \mathrm{C}$ on 12 July (data not shown) whereas surface waters from areas with no ice cover are warmer and typically $1-2^{\circ} \mathrm{C}$ at this time of year ${ }^{9,29,30}$. The under-ice algae were clearly 

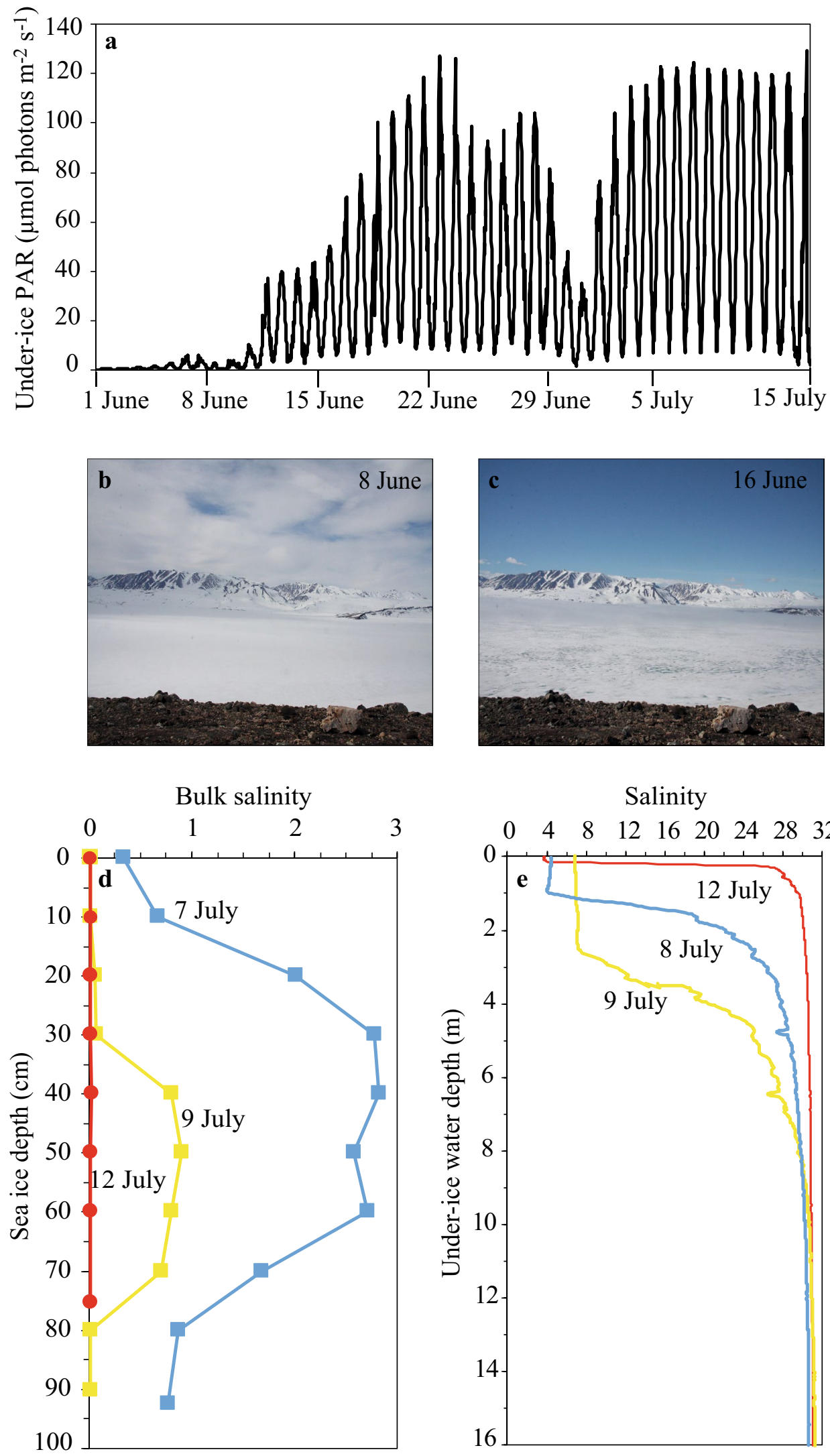

Salinity

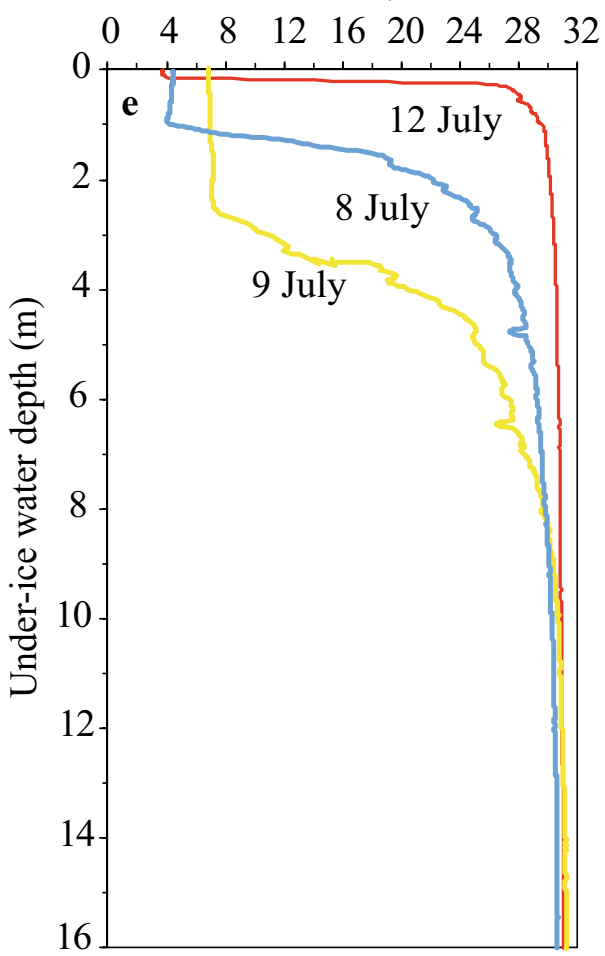

Figure 1. Physico-chemical properties of sea ice and seawater. Development of (a) under ice irradiance (PAR, $\mu \mathrm{mol}$ photons $\left.\mathrm{m}^{-2} \mathrm{day}^{-1}\right),(\mathbf{b})$ melt pond coverage on sea ice $(\sim 0 \%),(\mathbf{c})$ melt pond coverage on sea ice $(\sim 10 \%)$, (d) sea ice bulk salinity and (e) under-ice water salinity in Young Sound, NE Greenland, during the sea ice melting season in 2017. 

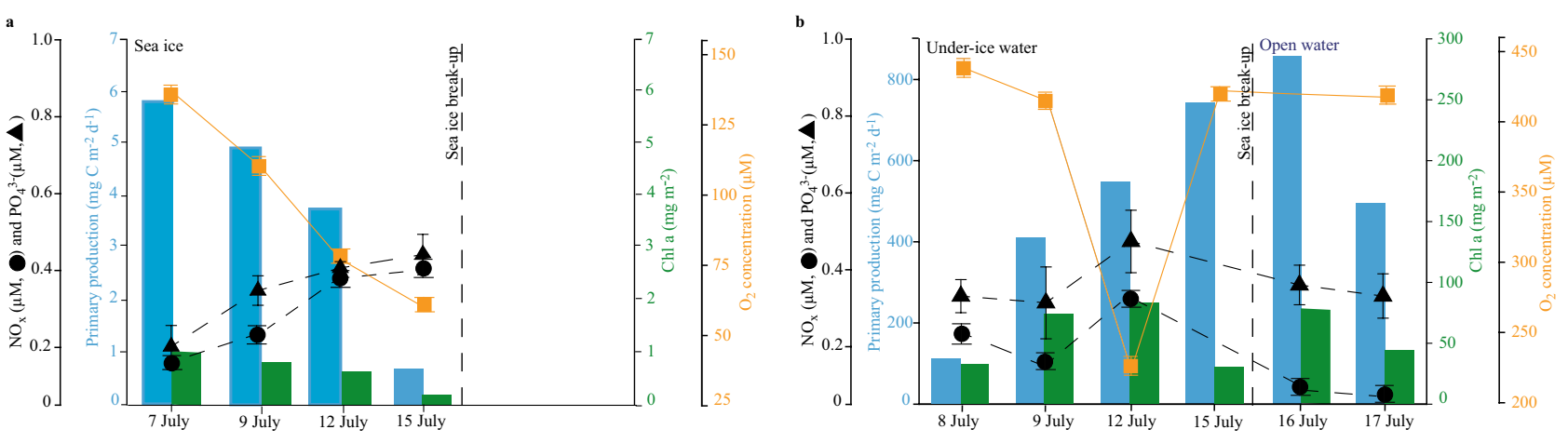

Figure 2. Comparison of sea ice and seawater biomass and productivity. Temporal development of (a) sea ice integrated primary production in $\mathrm{mg} \mathrm{C} \mathrm{m}^{-2}$ day $^{-1}$ (blue bars), integrated Chl $a$ in $\mathrm{mg} \mathrm{m}^{-2}$ (green bars), $\mathrm{NO}_{\mathrm{x}}$ concentration in $\mu \mathrm{M}$ (black circles), $\mathrm{PO}_{4}{ }^{3-}$ concentration in $\mu \mathrm{M}$ (black triangles) and $\mathrm{O}_{2}$ bulk concentration in $\mu \mathrm{M}$ (orange squares) and (b) under-ice and open water integrated primary production in $\mathrm{mg} \mathrm{C} \mathrm{m}^{-2} \mathrm{day}^{-1}$ (blue bars), integrated $\mathrm{Chl} a$ in $\mathrm{mg} \mathrm{m}^{-2}$ (green bars), $\mathrm{NO}_{\mathrm{x}}$ concentration in $\mu \mathrm{M}$ at $1 \mathrm{~m}$ (black circles), $\mathrm{PO}_{4}^{3-}$ concentration in $\mu \mathrm{M}$ at $1 \mathrm{~m}$ (black triangles) and $\mathrm{O}_{2}$ bulk concentration in $\mu \mathrm{M}$ at $1 \mathrm{~m}$ (orange squares). The data points represent the average of triplicate samples; error bars indicate SD of the mean.

acclimated to low light conditions given the relatively low under-ice $E_{\mathrm{k}}$ values (mean of $75 \mu \mathrm{mol}$ photons $\mathrm{m}^{-2} \mathrm{~s}^{-1}$ ) derived from ${ }^{14} \mathrm{C}$ incubations (Fig. S1), in comparison to values for under-ice and open-water phytoplankton in other actively blooming populations in Arctic studies ${ }^{11}$. In addition, the presence of the haptophytes and the taxonomic composition of the under-ice phytoplankton community was different from the most abundant open water planktonic species in Young Sound fjord ${ }^{31}$.

The first record of a Chrysochromulina under-ice bloom was in the brackish Baltic Sea at a salinity of 5-6 ${ }^{19}$. Similarly, the cells observed in this study were dominated by small $(3-5 \mu \mathrm{m})$ rounded cells with two long flagella and in many cases a long and coiled haptonema typical of e.g., the toxic mixotrophic species Prymnesium polylepis and Chrysochromulina leadbeateri. The under-ice bloom provided up to $740 \mathrm{mg} \mathrm{C} \mathrm{m}^{-2} \mathrm{day}^{-1}$ of new production (Fig. 2b, blue bars) and was primarily dominated by mixotrophic haptophytes with a relative abundance of $64 \%$, as compared to $36 \%$ relative abundance of typical strictly autotrophic phytoplankton species (Fig. 3 ). This productivity was four times higher than previously measured in open water phytoplankton blooms in Young Sound ${ }^{8,11}$. This documents the importance of such under-ice blooms driven by mixotrophic haptophytes (Fig. 3). We suggest that under-ice blooms driven by mixotrophic algae are an overlooked succession phenomenon in nutrient-depleted and freshwater-influenced environments in the Arctic, which could imply a shift in the dominant algae species driven by freshening.

The proposed link between high under-ice productivity and mixotrophy is further supported by the low bulk $\mathrm{NO}_{\mathrm{x}}$ concentration in sea ice and under-ice water $(<0.4 \mu \mathrm{M}$; Fig. 2a,b, dashed black line). Assuming that nutrient uptake followed the standard Redfield-Brzezinski ratio of 106C:16N:15Si:1P, $\mathrm{NO}_{\mathrm{x}}$ appears $(\mathrm{N}: \mathrm{P}$ ratio $<1)$ to have been deficient both in sea ice and seawater (Fig. 2a,b, dashed black lines). Our observations therefore challenge the classical view that limiting nutrient concentrations control algal biomass, as we observed an acute 9-day long under-ice bloom initiated under these nutrient-limited conditions. This suggests that mixotrophy is a strategy that might provide a growth benefit in these Arctic brackish waters where nutrients are not stoichiometrically balanced. This is supported by the measurements of biomass-specific productivity and maximum quantum yield $\left(F_{v} / F_{m}\right)$ in Table 1 , which verify that microalgae collected from sea ice and under-ice water were viable and photosynthetically active under these nutrient-limited conditions. The ongoing freshening of Young Sound and the Arctic Ocean with increased stratification and reduced vertical nutrient fluxes can accordingly promote mixotrophic-dominated algae blooms. Fundamental knowledge about the mechanisms driving these sub-ice blooms is important if we want to forecast their role and future prevalence. Therefore, we suggest that further expeditions aim to improve the understanding of these extensive under-ice blooms driven by potentially toxic mixotrophic haptophyte species. The consequences for the Arctic marine ecosystems and carbon budgets of the shift in the dominant algae to a potentially mixotrophic haptophyte species are important focus areas for future studies.

\section{Materials and methods}

Abiotic parameters. Sampling was conducted during the sea ice melting season in Young Sound, NE Greenland $\left(74^{\circ} 16^{\prime} 50 \mathrm{~N}, 20^{\circ} 18^{\prime} 43 \mathrm{~W}\right)$ in 2017 . The under-ice PAR measurements were obtained from a new and calibrated Odyssey PAR censor (Dataflow Systems) mounted on a cable and placed $2.4 \mathrm{~m}$ below the ice between 1 June and 7 July 2017. Under-ice PAR time-series were extended to 15 July by applying the transmittance of the ice (0.09), determined as ratio between measured CTD and surface PAR from the nearby Zackenberg Research station (https://data.g-e-m.dk/). Sea ice cores were collected on four occasions (7, 9, 12 and 15 July 2017) using a MARK II coring system (Kovacs Enterprises). All samples were collected within a $10 \mathrm{~m}^{2}(3.2 \mathrm{~m} \times 3.2 \mathrm{~m})$ quadrat. Triplicate cores were collected for physical and chemical samples during each sampling and cores for biological parameters were sampled in duplicate. The under-ice seawater samples were collected on four occasions $(8,9,12$ and 15 July 2017) using a Niskin (General Oceanics) water sampler at three depths: $1 \mathrm{~m}, 15 \mathrm{~m}$ and $30 \mathrm{~m}$. The sea 


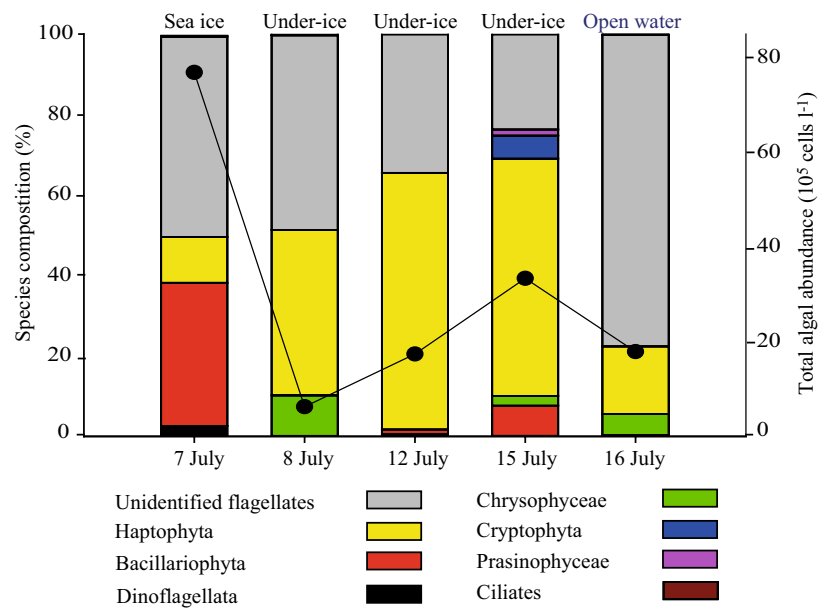

Figure 3. Algal community composition. Temporal development of algal species composition (\%) in the entire Sea ice column and under-ice water at $1 \mathrm{~m}$ (bars) and the total algal abundance (black circles).
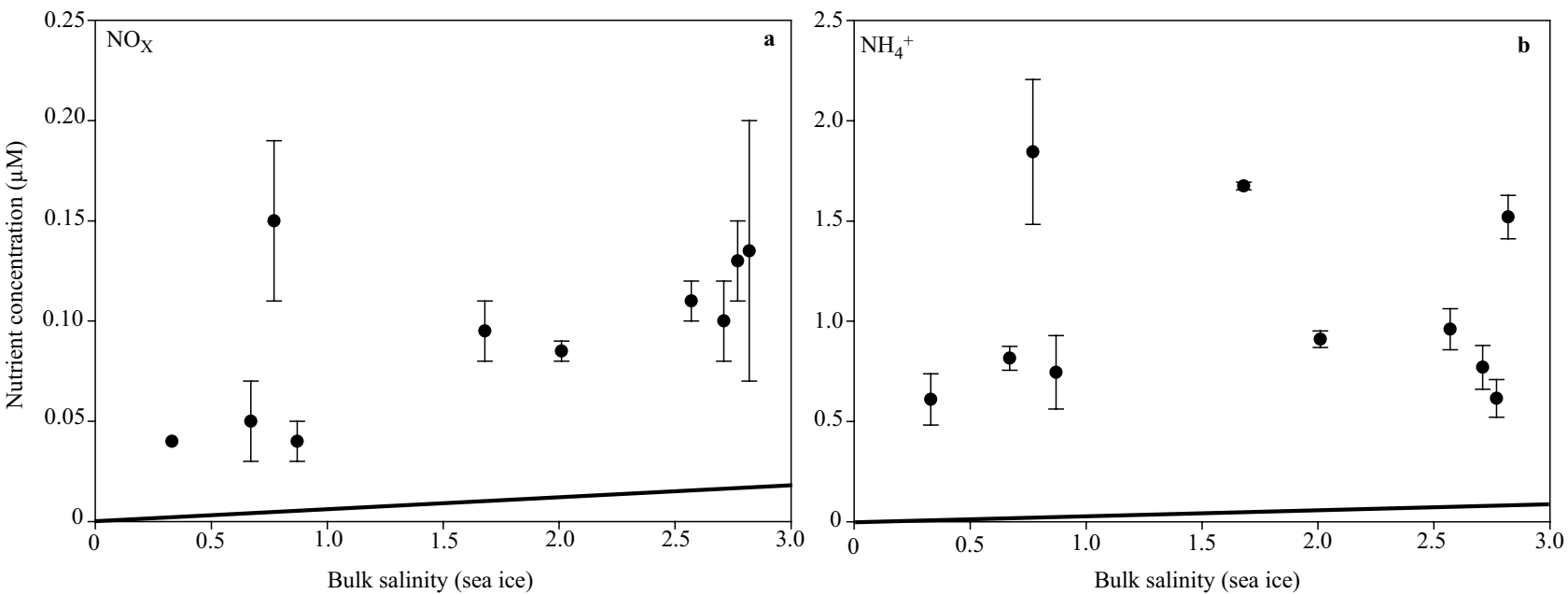

Figure 4. Sea ice nutrient concentrations in relation to salinity. Concentrations of (a) $\mathrm{NO}_{\mathrm{x}}$ and (b) $\mathrm{NH}_{4}^{+}$versus bulk salinity in sea ice prior to the complete brine drainage event. The solid line indicates the expected dilution line predicted from salinity and nutrient concentrations in seawater (15 m depth, salinity of 33). Values below the dilution line indicate nutrient depletion; values above it indicates either production or net accumulation. Data points represents treatment mean $\pm \operatorname{SD}(n=3)$.

ice cover broke up on 15 July after which the ice floes were transported out of the fjord by winds and tides. Open seawater samples were thereafter collected twice (16 and 17 July 2017) also at three depths: $1 \mathrm{~m}, 15 \mathrm{~m}$ and $30 \mathrm{~m}$. Vertical profiles of temperature, salinity, irradiance (photosynthetically active radiation; PAR) and fluorescence in the under-ice and open seawater column were measured using a CTD profiler (Seabird SBE19plus) equipped with additional sensors for Photosynthetic Active Radiation (Biospherical QSP-2350L Scalar sensor).

The air temperature was measured $2 \mathrm{~m}$ above the melt pond, and vertical profiles of temperature within the ice were measured using a thermometer (Testo). Light attenuation (used to calculate in situ primary production of the sea ice) was determined using standard methods $s^{32}$. The sea ice sections were placed in plastic containers and transported back to the laboratory in thermally insulated boxes. To determine bulk concentrations of $\mathrm{O}_{2}$ and $\mathrm{TCO}_{2}\left(\mathrm{TCO}_{2}\right.$ was used in this study to calculate potential primary production; Fig. S1) in sea ice, three sea ice cores were cut into $10 \mathrm{~cm}$ sections and placed immediately in gas-tight plastic bags ${ }^{33}$ and transported back to the laboratory in thermally insulated boxes. $\mathrm{TCO}_{2}$ and $\mathrm{O}_{2}$ were determined using standard methods ${ }^{33,34}$. Average values of triplicate samples are reported.

In the laboratory, sea ice sections were weighed for later determination of density and then melted in the dark over a 2-day period at $3 \pm 1{ }^{\circ} \mathrm{C}$. Conductivity of melted sea ice was measured (Thermo Orion-star with an Orion $013610 \mathrm{MD}$ conductivity cell) and converted to bulk salinity ${ }^{35}$. Average values of triplicate samples are reported.

Unfiltered under-ice and open seawater was transferred by gastight Tygon tubing to tubes (12 ml Exetainer) for $\mathrm{TCO}_{2}{ }^{33}$ and $\mathrm{O}_{2}{ }^{34}$ analysis following the standard analysis procedure. 


\begin{tabular}{|l|l|l|l|l|}
\hline \multirow{2}{*}{ Sampling date } & \multicolumn{2}{|l|}{ Under-ice and open water } & Sea ice & \multicolumn{2}{l|}{$\boldsymbol{F}_{\mathbf{v}} \boldsymbol{F}_{\mathrm{m}}$} \\
\cline { 2 - 5 } & Biomass specific productivity & $\boldsymbol{F}_{\mathrm{v}} / \boldsymbol{F}_{\mathrm{m}}$ & Biomass specific productivity & $0.22 \pm 0.03$ \\
\hline 7 July & - & - & 5.53 & - \\
\hline 8 July & 4.40 & $0.24 \pm 0.04$ & - & $0.21 \pm 0.03$ \\
\hline J July & 5.80 & $0.12 \pm 0.02$ & 5.87 & $0.11 \pm 0.04$ \\
\hline 12 July & 6.25 & $0.13 \pm 0.01$ & 5.61 & $0.13 \pm 0.05$ \\
\hline 15 July & 25.40 & $0.35 \pm 0.10$ & 3.95 & - \\
\hline 16 July & 10.96 & $0.21 \pm 0.07$ & - & - \\
\hline 17 July & 10.60 & $0.22 \pm 0.06$ & - & - \\
\hline
\end{tabular}

Table 1. Algal productivity and photobiology. Biomass specific productivity (mg C mg Chl $a^{-1}$ day $\left.^{-1}\right)$ and algal photobiology from 7 to 17 July in under-ice water $(1 \mathrm{~m})$, open seawater $(1 \mathrm{~m})$ and sea ice. Data points represents treatment mean $\pm \mathrm{SD}(\mathrm{n}=3)$.

Chemical and biotic parameters. Triplicate melted sea ice cores (10 cm sections) and under-ice and open seawater samples $(1 \mathrm{~m}, 15 \mathrm{~m}, 30 \mathrm{~m})$ were analysed for inorganic nutrients $\left(\mathrm{PO}_{4}{ }^{3-}, \mathrm{NO}_{2}{ }^{-}+\mathrm{NO}_{3}{ }^{-}\left(\mathrm{NO}_{\mathrm{x}}\right)\right.$ and $\mathrm{NH}_{4}^{+}$), Chlorophyll $a(\mathrm{Chl} a)$ and photosynthetic activity. Duplicate samples were collected for primary production and algal abundance. Melting of sea ice was carried out following the protocols of Lund-Hansen et al. ${ }^{17}$ to avoid osmotic shock during ice melt, and photosynthetic and photobiological parameters are therefore maximum values.

Potential primary production was determined in melted sea ice cores cut into three sections (top, middle and bottom), and under-ice and open seawater at three depths $(1 \mathrm{~m}, 15 \mathrm{~m}$ and $30 \mathrm{~m})$ incubated for 3.15-6.49 $\mathrm{h}$ at $1 \pm 1{ }^{\circ} \mathrm{C}$ at eleven laboratory light intensities $(299 \pm 128,131 \pm 35,97 \pm 47,62 \pm 28,47 \pm 24,35 \pm 19,27 \pm 15,17 \pm 8$, $13 \pm 7,8 \pm 6,0 \mu \mathrm{mol}$ photons $\mathrm{m}^{-2} \mathrm{~s}^{-1}$ ) using the $\mathrm{H}^{14} \mathrm{CO}_{3}{ }^{-}$incubation technique ${ }^{36}$, and following the primary production procedure ${ }^{37}$. The potential primary production $\left(\mu \mathrm{g} \mathrm{Cl}^{-1} \mathrm{~h}^{-1}\right)$ measured in the laboratory for different sea ice depths was plotted against the eleven laboratory light intensities and fitted to the function ${ }^{38}$ (Fig. S1). An estimate of primary production was calculated for each hour and sea ice depth using hourly in situ PAR hourly averages received through the Greenland Ecosystem Monitoring Programme (https://data.g-e-m.dk/). Average values of duplicate samples are reported.

For determining Chl $a$ concentrations in melted sea ice and under-ice and open seawater, a known volume was filtered onto $25-\mathrm{mm}$ Whatman GF/F filters. The filters were extracted for $18 \mathrm{~h}$ in $96 \%$ ethanol ${ }^{39}$ and analysed fluorometrically (TD-700, Turner Designs) before and after addition of $200 \mu \mathrm{l}$ of a $1 \mathrm{M} \mathrm{HCl}$ solution. The fluorometer was calibrated against a pure Chl $a$ standard (Turner Designs). Average values of triplicate samples are reported.

For determining inorganic nutrient concentrations, triplicate samples of melted sea ice, under-ice water and seawater without ice were filtered through $0.45 \mu \mathrm{m}$ filters (Q-Max GPF syringe filters) into $6.5 \mathrm{ml}$ scintillation vials and frozen $\left(-19^{\circ} \mathrm{C}\right)$ for further analysis of $\mathrm{PO}_{4}{ }^{3-}, \mathrm{NO}_{\mathrm{x}}$ and $\mathrm{NH}_{4}$. The concentrations were measured on a Seal QuAAtro autoanalyzer using standard colorimetric methods. Average values of triplicate samples are reported.

Pulse amplitude modulated (PAM) fluorometry (Phyto-PAM Phytoplankton Analyzer, Heinz Waltz GmbH, Germany) was applied to measure algae photoacclimation and photosynthetic activity in triplicate samples from melted sea ice core sections $(10 \mathrm{~cm})$, under-ice, and at depths $(1 \mathrm{~m})$ in open seawater with no ice. All PAM measurements were conducted in the dark to keep algae dark-incubated and the photosynthetic parameters were derived by means of the rapid light curve technique ${ }^{40}$ and the curve-fitting algorithm ${ }^{41}$. Average values of triplicate samples of maximum quantum yield $\left(F_{v} / F_{m}\right)$ are reported. Temperature in a snow bath with measuring unit was controlled by an US-T Temperature Control Unit and kept close to $1^{\circ} \mathrm{C}$. Temperature of the samples was measured by a thermometer (LT-101, Lab Thermometer IP65, TFA Dostmann/Wertheim).

For algal abundance measurements, samples of melted sea ice and under-ice and open seawater were fixed with acidic Lugol's solution (final concentration of $1 \%)$ and stored dark and cold $\left(3 \pm 1{ }^{\circ} \mathrm{C}\right)$. Algal cells were identified and counted from light-microscopy analyses using the Utermöhl sedimentation technique. Algae cells were analysed within 2 months of collection, average values of duplicate samples are reported.

Using light microscopy, it is not possible to identify small naked flagellates such as the haptophytes to species level. The taxonomy of the haptophytes is currently under revision, and the bloom forming mixotrophic species formerly known as Chrysochromulina polylepis, which is a typical haptophyte with a long and coiling haptonema, has been transferred to the genus Prymnesium.

\section{Data availability}

The data produced during the current study are available from corresponding author based on a reasonable request.

Received: 23 October 2020; Accepted: 20 January 2021

Published online: 03 February 2021

\section{References}

1. Arrigo, K. R. \& Dijken, G. L. Secular trends in Arctic Ocean net primary production. J. Geophys. Res. Oceans. 116, C09011 (2011).

2. Thomas, D. N. Sea Ice Ch 4 (Wiley Blackwell, Oxford, 2017). 
3. Arrigo, K. R. et al. Massive phytoplankton blooms under Arctic sea ice. Science 336, 1408-1408 (2012).

4. Assmy, P. et al. Leads in Arctic pack ice enable early phytoplankton blooms below snow-covered sea ice. Sci. Rep. 7, 40850 (2016).

5. Horvat, C. et al. The frequency and extent of sub-ice phytoplankton bloom in the Arctic Ocean. Sci. Adv. 3, e1601191 (2017).

6. Ardyna, M. et al. Environmental drivers of under-ice phytoplankton bloom dynamics in the Arctic Ocean. Elem. Sci. Anth. 8, 30 (2020).

7. Ardyna, M. et al. Under-ice phytoplankton blooms: Shedding light on the "invisible" part of Arctic primary production. Front. Mar. Sci. 7, 608032 (2020).

8. Rysgaard, S. \& Glud, R. N. Carbon cycling in Arctic marine ecosystems: Case study Young Sound (ed. Rysgaard, S. \& Glud, R. N.) 62-94 (Meddelelser om Grønland, Bioscience Vol 58, Copenhagen, Denmark, the Commission for Scientific Research in Greenland, 2007).

9. Meire, L. et al. Marine-terminating glaciers sustain high productivity in Greenland fjords. Glob. Chang. Biol. 23, 5344-5357 (2017).

10. Randelhoff, A. et al. Pan-Arctic Ocean primary production constrained by turbulent nitrate fluxes. Front. Mar. Sci. 7, 150 (2020).

11. Holding, J. M. et al. Seasonal and spatial patterns of primary production in a high-latitude fiord affected by Greenland Ice Sheet run-off. Biogeosciences 16, 3777-3792 (2019).

12. Juul-Pedersen, T. et al. Seasonal and interannual phytoplankton production in a sub-Arctic tidewater outlet glacier fjord, SW Greenland. Mar. Ecol. Prog. Ser. 524, 27-38 (2015).

13. Sejr, M. K. et al. Evidence of local and regional freshening of Northeast Greenland coastal waters. Sci. Rep. 7, 13183 (2017).

14. Boone, W. et al. Circulation and ford-shelf exchange during the ice-covered period in Young Sound-Tyrolerfjord, Northeast Greenland $\left(74^{\circ} \mathrm{N}\right)$. Estuar. Coast. Shelf Sci. 194, 205-216 (2017).

15. Haine, T. W. N. et al. Arctic freshwater export: Status, mechanisms, and prospects. Glob. Planet Change 125, 13-35 (2015).

16. Carmack, E. C. et al. Freshwater and its role in the Arctic Marine System: Sources, disposition, storage export, and physical and biogeochemical consequences in the Arctic and global ocean. J. Geophys. Res. Biogeosci. 121, 675-717 (2015).

17. Lund-Hansen, L. C. et al. Will low primary production rates in the Amundsen Basin (Arctic Ocean) remain low in a future ice-free setting, and what governs this production?. J. Mar. Syst. 205, 103287 (2020).

18. Dahl, E., Bagøien, E., Edvardsen, B. \& Stenseth, N. C. The dynamics of Chrysochromulina species in the Skagerrak in relation to environmental conditions. J. Sea. Res. 54, 15-24 (2005).

19. Hansen, P. J., Nielsen, T. G. \& Kaas, H. Distribution and growth of protists and mesozooplankton during a bloom of Chrysochromulina spp. (Prymnesiophyceae, Prymnesiales). Phycologia 34, 409-416 (1995).

20. Nielsen, T. G., Kiørboe, T. \& Bjørnsen, P. K. Effects of a Chrysochromulina polylepis subsurface bloom on the planktonic community. Mar. Ecol. Prog. Ser. 62, 21-35 (1990).

21. Hällfors, G. \& Niemi, Å. A Chrysochromulina (Haptophyceae) bloom under the ice in the Tvärminne Archipelago, southern coast of Finland. Acta Soc. Fauna Flora Fenn. 50, 89-104 (1974).

22. Manton, I. Chrysochromulina tenuispine sp. nov. from arctic Canada. Br. Phycol. J. 13, 227-234 (1978).

23. Green, J. C. \& Leadbeater, B. S. C. The Haptophyte Algae ch. 13 (Systematics Association, London, 1994).

24. Hansen, P. J. \& Hjorth, M. Growth and grazing responses of Chrysochromulina ericina (Prymnesiophyceae): The role of irradiance, prey concentration and pH. Mar. Biol. 141, 975-983 (2002).

25. Anderson, R., Charvet, S. \& Hansen, P. J. Mixotrophy in chlorophytes and haptophytes-Effect of irradiance, macronutrient micronutrient and vitamin limitation. Front. Microbiol. 9, 1704 (2018).

26. Anderson, R. \& Hansen, P. J. Meteorological conditions induce strong shifts in mixotrophic and heterotrophic flagellate bacterivory over small spatio-temporal scales. Limnol. Oceanogr. 9999, 1-11 (2019).

27. McKie-Krisberg, Z. M., Gast, R. J. \& Sanders, R. W. Physiological responses of three species of Antarctic mixotrophic phytoflagellates to changes in light and dissolved nutrients. Microbiol. Ecol 70, 21-29 (2015).

28. McKie-Krisberg, Z. M., Sanders, R. W. \& Gast, R. J. Evaluation of mixotrophy-associated gene expression in two species of polar marine algae. Front. Mar. Sci. 5, 273 (2018).

29. Rysgaard, S., Nielsen, T. G. \& Hansen, B. W. Seasonal variation in nutrients, pelagic primary production and grazing in a highArctic coastal marine ecosystem, Young Sound, Northeast Greenland. Mar. Ecol. Prog. Ser. 179, 13-25 (1999).

30. Bendtsen, J., Mortensen, J. \& Rysgaard, S. Seasonal surface layer dynamics and sensitivity to runoff in a high Arctic fjord (Young Sound/Tyrolerford, $\left.74^{\circ} \mathrm{N}\right)$. J. Geophys. Res. Oceans. 119, 1-18 (2014).

31. Krawczyk, D. W. et al. Spatial and temporal distribution of planktonic protists in the East Greenland fjord and offshore waters. Mar. Ecol. Prog. Ser. 538, 99-116 (2015).

32. Søgaard, D. H., Deming, J. W., Meire, L. \& Rysgaard, S. Effects of microbial processes and $\mathrm{CaCO}_{3}$ dynamics on inorganic carbon cycling in snow-covered Arctic winter sea ice. Mar. Ecol. Prog. Ser. 611, 31-44 (2019).

33. Rysgaard, S. et al. Ikaite crystal distribution in winter sea ice and implications for $\mathrm{CO}_{2}$ system dynamics. Cryosphere 7, 707-718 (2013).

34. Søgaard, D. H. et al. Autotrophic and heterotrophic activity in Arctic first-year sea ice: Seasonal study from Malene Bight, SW Greenland. Mar. Ecol. Prog. Ser. 419, 31-45 (2010).

35. Grasshoff, K., Kremling, K. \& Ehrhardt, M. Methods of Seawater Analysis (WILEY-VCH Verlag GmbH, Weinheim, 1999).

36. Steemann-Nielsen, E. The use of radio-active carbon $\left(\mathrm{C}^{14}\right)$ for measuring organic production in the sea. ICES J. Mar. Sci. 18, $117-140$ (1952).

37. Søgaard, D. H. et al. The relative contributions of biological and abiotic processes to carbon dynamics in subarctic sea ice. Polar Biol. 36, 1761-1777 (2013).

38. Platt, T., Gallegos, C. L. \& Harrison, W. G. Photoinhibition of photosynthesis in natural assemblages of marine phytoplankton. J. Mar. Res. 38, 687-701 (1980).

39. Jespersen, A. M. \& Christoffersen, K. Measurements of chlorophyll-a from phytoplankton using ethanol as extraction solvent. Arch. Hydrobiol. 109, 445-454 (1987).

40. Ralph, P. J. \& Gademann, R. Rapid light curves: A powerful tool to assess photosynthetic activity. Aquat. Bot. 82, 222-237 (2005).

41. Jassby, A. D. \& Platt, T. Mathematical formulation of the relationship between photosynthesis and light for phytoplankton. Limnol. Oceanogr. 21, 540-547 (1976).

\section{Acknowledgements}

We thank Bjarne Jensen and Kunuk Lennert for outstanding assistance in the field and laboratory. We greatly appreciate the data provided by Greenland Ecology Monitoring (https://data.g-e-m.dk/). Co-authors are listed based on weight of contribution. This study received financial support from the Arctic Research Centre of Aarhus University and the Commission for Scientific Investigations in Greenland (KVUG). D.H.S. was supported financially by KVUG and the DANCEA project "In situ $\mathrm{pH}$ and $p \mathrm{CO}_{2}$ in more details". M.K.S. was supported by the DANCEA project "De-icing Arctic Coasts". S.R. was supported by NSERC in Canada. This is a contribution to the Arctic Science Partnership (ASP) asp-net.org. 


\section{Author contributions}

D.H.S., M.K.S. and L.C.L-H. designed the study. D.H.S. and A.S. conducted the sampling in Young Sound in 2017. D.H.S., A.S., S.L. and P.A. performed laboratory analyses. D.H.S., P.J.H., P.A., L.C.L-H. and B.K.S. analysed data. D.H.S., L.C.L-H., B.K.S., S.R. and P.J.H. drafted the manuscript. All authors contributed critically to the drafts and gave final approval for publication.

\section{Competing interests}

The authors declare no competing interests.

\section{Additional information}

Supplementary Information The online version contains supplementary material available at https://doi. org/10.1038/s41598-021-82413-y.

Correspondence and requests for materials should be addressed to D.H.S.

Reprints and permissions information is available at www.nature.com/reprints.

Publisher's note Springer Nature remains neutral with regard to jurisdictional claims in published maps and institutional affiliations.

(c) (1) Open Access This article is licensed under a Creative Commons Attribution 4.0 International License, which permits use, sharing, adaptation, distribution and reproduction in any medium or format, as long as you give appropriate credit to the original author(s) and the source, provide a link to the Creative Commons licence, and indicate if changes were made. The images or other third party material in this article are included in the article's Creative Commons licence, unless indicated otherwise in a credit line to the material. If material is not included in the article's Creative Commons licence and your intended use is not permitted by statutory regulation or exceeds the permitted use, you will need to obtain permission directly from the copyright holder. To view a copy of this licence, visit http://creativecommons.org/licenses/by/4.0/.

(C) The Author(s) 2021 